\title{
Application of Multi-Objective Optimization on the Basis of Ratio Analysis (MOORA) Method for Bank Branch Location Selection
}

\author{
Ali Görener, $\mathrm{PhD}^{\mathrm{a}}$, Hasan Dinçer, $\mathrm{PhD}^{\mathrm{b}}$, Ümit Hacıoğlu, $\mathrm{PhD}^{\mathrm{c}}$ \\ ${ }^{a}$ Department of International Logistics, Istanbul Commerce University, 34672, Istanbul, Turkey \\ ${ }^{b}$ Department of Capital Markets and Portfolio Management, Beykent University, 34500, Istanbul, Turkey \\ ${ }^{c}$ Department of Capital Markets and Portfolio Management, Beykent University, 34500, Istanbul, Turkey
}

\begin{abstract}
Location selection problem in banking is an important issue for the commercial success in competitive environment. There is a strategic fit between the location selection decision and overall performance of a new branch. Providing physical service in requested location as well as alternative distribution channels to meet profitable client needs is the current problematic to achieve the competitive advantage over the rivalry in financial system. In this paper, an integrated model has been developed to support in the decision of branch location selection for a new bank branch. Analytic Hierarchy Process (AHP) technique has been conducted to prioritize of evaluation criteria, and multi-objective optimization on the basis of ratio analysis (MOORA) method has been applied to rank location alternatives of bank branch.
\end{abstract}

Keywords: Location selection; Banking; Bank Branch; AHP; MOORA

\section{(C) 2013 Published by SSBFNET}

\section{Introduction}

Many countries before globalization strictly regulated the financial system, permitted limitedly to open branch abroad and restricted the international financial transactions in the worldwide. In this case, the competition in the financial system remained in the local area and new service \& products of the banking sector were provided for only national clients. The revealed situations such as incomparable pricing mechanism for particularly have given global services and were unable to get the most profitable global customers. These were the main problems in the lack of the global competition. By the globalization process, the productivity and efficiency in production economies has become an important concern to ensure the competitive advantage. Especially, the new economy process emerged by the 1990s requires to consider the strategic thinking such as competitive pricing, providing the service just in time and changing demand according the customer needs. Although all of the items are significantly related to the customeroriented beneficial determinants, the main problem for the firms is to find the strategies that reducing operational costs and determining attractive location as well as providing customer satisfaction.

Bank branch location is one of the most important strategic issues in the complex market competitiveness. Increasing new service facilities and internet-based banking applications force the firms to give face to face services more efficiently than competitors. That's why the nearest locations should be found to provide the most profitable and productive services for conscious customers.

\footnotetext{
${ }^{a}$ Corresponding author. Ali Görener, Tel.: +90 21655394 22. E-mail address: agorener@ticaret.edu.tr
} 
In this study, bank branch determinants have been revealed and related demographic, economic and investment parameters have been determined to find out the best branch location. AHP and MOORA method also have been considered to evaluate the best bank branch location in inter-country comparison.

\section{Bank Branch Location Selection}

It is necessary to focus on the productivity-enhancing strategies in order to achieve profitability in banking transactions. There are lots of items to get the productivity and efficiency in financial institutions. However, the branch location selection is the prominent issue in banking sector to increase the productivity and gains. Although gigantic empirical studies on efficiency and productivity of the banking sector, most of them only get weight to the internal and organizational factors to evaluate the branch performance. Also, they generally use the data envelopment analysis to appraise internal inputs. The selected studies on bank branch are seen in table 1.

Table 1. Selected Studies on Bank Branch

\begin{tabular}{|c|c|c|c|}
\hline Authors & Main Determinants & Methods & Goals \\
\hline $\begin{array}{l}\text { Boufounou, } \\
1995\end{array}$ & $\begin{array}{l}\text { Deposits, population, households, employment, firms in the trade sector, income, } \\
\text { characteristics of the owners' and competitors' bank branches, }\end{array}$ & $\begin{array}{l}\text { Regression } \\
\text { model }\end{array}$ & Bank branch planning, \\
\hline $\begin{array}{l}\text { Athanassopoul } \\
\text { os, } 1997\end{array}$ & Employees, computers, ATM, transactions, deposits and loans & $\begin{array}{l}\text { Data } \\
\text { envelopment } \\
\text { analysis }\end{array}$ & $\begin{array}{l}\text { Service quality and } \\
\text { efficiency, }\end{array}$ \\
\hline Hirtle, 2007 & $\begin{array}{l}\text { Deposits, loans, return on equity, market return, assests, capital ratio, entities, } \\
\text { Herfindahl-Hirschmann Index }\end{array}$ & Regression & $\begin{array}{l}\text { Impact of network and } \\
\text { bank performance }\end{array}$ \\
\hline $\begin{array}{l}\text { Liang, Ching, } \\
\text { Chan, } 2013\end{array}$ & $\begin{array}{l}\text { Return on asset, return on equity, tobin's Q, net interest marjin ratio, cost ratio, } \\
\text { characteristics of the branch and representative office, control variables }\end{array}$ & $\begin{array}{l}\text { Regression } \\
\text { analysis }\end{array}$ & $\begin{array}{l}\text { European Banks and } \\
\text { representative offices } \\
\text { performance }\end{array}$ \\
\hline Giokas, 2008 & $\begin{array}{l}\text { Personel costs, operating costs, interest and non-interest costs, loans, } \\
\text { deposits, interest and non-interest income }\end{array}$ & $\begin{array}{l}\text { Data } \\
\text { envelopment } \\
\text { analysis }\end{array}$ & Efficiency \\
\hline $\begin{array}{l}\text { Berger, } \\
\text { Leusner, } \\
\text { Mingo, } 1997 \\
\end{array}$ & $\begin{array}{l}\text { Operating costs, interest costs, consumer and business transactions, closed and } \\
\text { opened accounts, credits, debits, }\end{array}$ & Panel data & Merger and efficiency \\
\hline $\begin{array}{l}\text { Cerutti, } \\
\text { Ariccia, Peria, } \\
2007\end{array}$ & Internationalization strategy, size, business orientation, regulations, entry, & Probit model & organizational form \\
\hline $\begin{array}{l}\text { Dekker, Post, } \\
2001\end{array}$ & $\begin{array}{l}\text { Personell, workspace, loans, mortgages, insurance, computers, demographics, } \\
\text { competition }\end{array}$ & $\begin{array}{l}\text { Data } \\
\text { envelopment } \\
\text { analysis } \\
\end{array}$ & Production technology \\
\hline $\begin{array}{l}\text { Shyu, Chiang, } \\
2012\end{array}$ & $\begin{array}{l}\text { Staff, business personel, office rent, operating expenses, net interest spread } \\
\text { income, net fee income }\end{array}$ & $\begin{array}{l}\text { Data } \\
\text { envelopment } \\
\text { analysis }\end{array}$ & $\begin{array}{c}\text { Managerial efficiency } \\
\text { and environment } \\
\text { variables }\end{array}$ \\
\hline $\begin{array}{l}\text { Manandhar, } \\
\text { Tang, } 2002\end{array}$ & $\begin{array}{l}\text { Personnel expenses, supplies, office space, technology, labor, deposits and loans, } \\
\text { interest and non-interest expenses }\end{array}$ & $\begin{array}{l}\text { Data } \\
\text { envelopment } \\
\text { analysis } \\
\end{array}$ & $\begin{array}{c}\text { Effiency, internal } \\
\text { service quality, } \\
\text { benchmarking }\end{array}$ \\
\hline $\begin{array}{l}\text { Paradi, Rouatt, } \\
\text { Zhu, } 2011\end{array}$ & Personal and commercial relationship, specialist, manager, transactions & $\begin{array}{l}\text { Data } \\
\text { envelopment } \\
\text { analysis } \\
\end{array}$ & Bank branch network \\
\hline $\begin{array}{l}\text { Paradi, Zhu, } \\
\text { Edelstein, } 2012\end{array}$ & Sales, service, management, day-day banking, borrowing, investment, transactions & $\begin{array}{l}\text { Data } \\
\text { envelopment } \\
\text { analysis } \\
\end{array}$ & Branch Management \\
\hline Ramirez, 2003 & $\begin{array}{l}\text { Assests, capital, deposit, risky assests, failure rate, market power, establishment, } \\
\text { population, illiteracy rate, manufacturing }\end{array}$ & Logit regression & $\begin{array}{l}\text { Bank failures, unit } \\
\text { banks }\end{array}$ \\
\hline $\begin{array}{l}\text { Spyropoulos, } \\
\text { Balaras, } 2011\end{array}$ & Construction details and annual energy consumption & $\begin{array}{l}\text { Sensitivity } \\
\text { Analysis }\end{array}$ & $\begin{array}{l}\text { Energy consumption } \\
\text { and office buildings }\end{array}$ \\
\hline $\begin{array}{l}\text { Meepadung, } \\
\text { Tang, Khang, } \\
2009\end{array}$ & $\begin{array}{l}\text { Labor, empoyees, interest and non-interest expenses, deposit, loans, IT-based } \\
\text { transaction, interest and non-interest income }\end{array}$ & $\begin{array}{l}\text { Data } \\
\text { envelopment } \\
\text { analysis } \\
\end{array}$ & $\begin{array}{l}\text { Efficiency and IT- } \\
\text { based technology }\end{array}$ \\
\hline $\begin{array}{l}\text { Wu, Yang, } \\
\text { Liang, } 2006\end{array}$ & $\begin{array}{l}\text { Personel, equipment, occupancy, expenses, income, population, density, economy, } \\
\text { deposits, loans }\end{array}$ & $\begin{array}{l}\text { Data } \\
\text { envelopment } \\
\text { analysis }\end{array}$ & $\begin{array}{c}\text { The efficiency of } \\
\text { Cross-region bank } \\
\text { branches }\end{array}$ \\
\hline
\end{tabular}


The focus points of the bank branch-based studies can be listed as the planning, managerial issues and service quality in the efficiency, technology and network etc. Nevertheless, the evaluation criteria in the branch selection generally omit the external factors on the basis of the economics and investment. The methods are mostly limited to the regression and data envelopment analysis. In this study, comprehensive framework for inter-country bank branch location is conducted. However, banking and investment-based parameters as well as economic and demographic criteria in the target countries are considered for the branch location selection.

\subsection{Evaluation framework}

In this study, our location selection model contains three main criteria with eleven sub-criteria. Demographic criteria $\left(\mathrm{C}_{1}\right)$ include three sub-criteria; total population $\left(\mathrm{C}_{11}\right)$, literacy rate $\left(\mathrm{C}_{12}\right)$ and urbanization rate $\left(\mathrm{C}_{13}\right)$. Economic criteria $\left(\mathrm{C}_{2}\right)$ contain four sub-criteria namely gross domestic product $\left(\mathrm{C}_{21}\right)$, spending on education $\left(\mathrm{C}_{22}\right)$, employment rate $\left(\mathrm{C}_{23}\right)$ and inflation rate in consumer prices $\left(\mathrm{C}_{24}\right)$ Investment and banking criteria $\left(\mathrm{C}_{3}\right)$ consist four criteria namely total business spending on investment $\left(\mathrm{C}_{31}\right)$, number of domestic companies listed on the stock exchange $\left(\mathrm{C}_{32}\right)$, Bank capital to assests ratio $\left(\mathrm{C}_{33}\right)$ and domestic credit by banking sector $\left(\mathrm{C}_{34}\right)$.

Table 2. List of evaluation criteria for bank branch location selection

\begin{tabular}{|c|c|}
\hline Main Criteria & Sub-Criteria \\
\hline \multirow{3}{*}{$\mathrm{C}_{1}$-Demographic criteria } & $\mathrm{C}_{11}$-Total population \\
\hline & $\mathrm{C}_{12}$-Literacy rate $(\%)$ \\
\hline & $\mathrm{C}_{13}$-Urbanization rate $(\%)$ \\
\hline \multirow{4}{*}{$\mathrm{C}_{2}$ - Economic criteria } & $\mathrm{C}_{21}$-Gross domestic product (millions of US \$) \\
\hline & $\mathrm{C}_{22}$-Spending on education ( $\%$ of GDP) \\
\hline & $\mathrm{C}_{23}$-Employment rate $(\%)$ \\
\hline & $\mathrm{C}_{24}$-Inflation rate in consumer prices $(\%)$ \\
\hline \multirow{4}{*}{$\mathrm{C}_{3}$ - Investment and Banking criteria } & $\mathrm{C}_{31}$-Total business spending on investment ( $\%$ of GDP) \\
\hline & $\mathrm{C}_{32}$-Number of domestic companies listed on the stock exchange \\
\hline & $\mathrm{C}_{33}$-Bank capital to assests ratio $(\%)$ \\
\hline & $\mathrm{C}_{34}$-Domestic credit by banking sector ( $\%$ of GDP) \\
\hline
\end{tabular}


Four possible location alternatives $\left(\mathrm{L}_{1}, \mathrm{~L}_{2}, \mathrm{~L}_{3}\right.$ and $\left.\mathrm{L}_{4}\right)$ are determined as alternatives by the XYZ Corp. to open its new bank branch. Hierarchical structure of location selection problem is given in Figure 1.

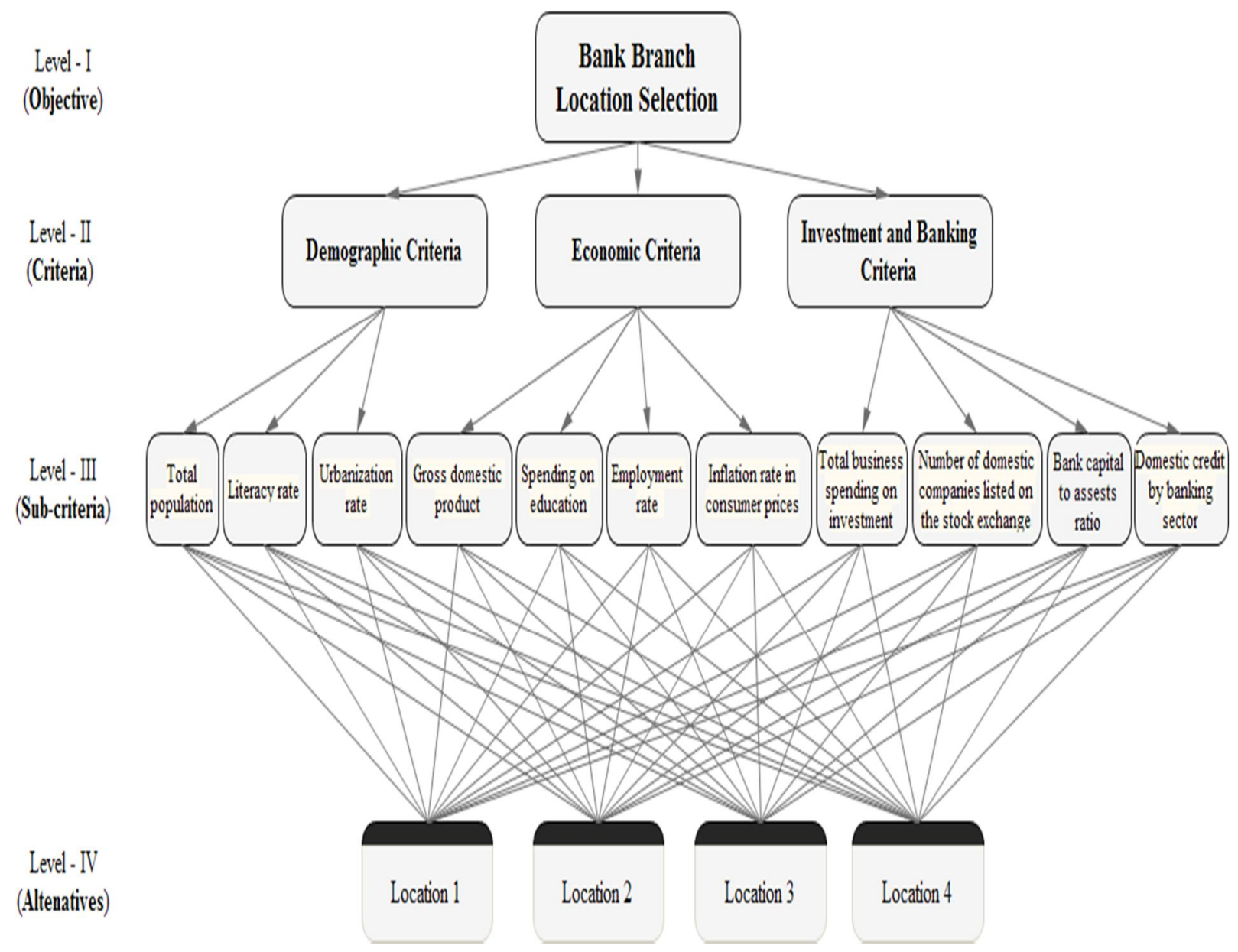

Figure 1. Location selection problem hierarchy

\section{Research Methods}

\subsection{AHP Method}

The AHP is an effective decision making method to solve multi-dimensional and complex problems. AHP performs pairwise comparison matrices to decompose and solve a multiple criteria decision making problems with different and conflicting criteria. AHP method is based on three main principles: structure of the model; comparative judgment of the criteria and/or alternatives; synthesis of the priorities.

Steps of the AHP method as follows (Saaty, 1980, 1990, 2008):

Step 1: Developing the hierarchical structure.

A decision problem is structured as a hierarchy. With the AHP, the goal, decision criteria and alternatives are arranged in a hierarchical structure similar to a family tree (Albayrak and Erensal, 2004; Liu et al., 2012). 


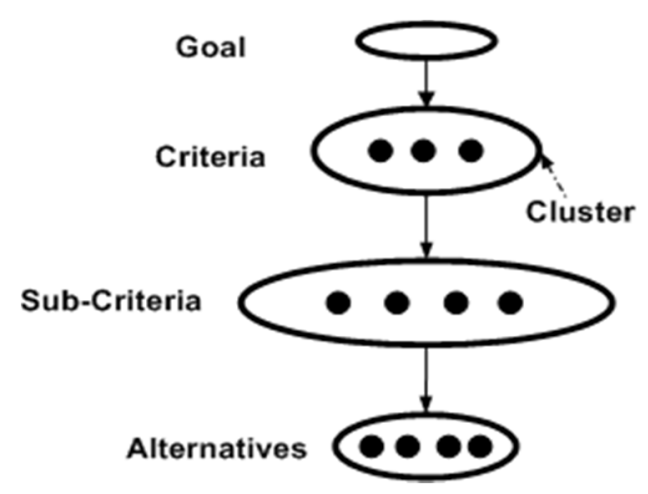

Figure 2. Hierarchical structure of AHP

Step 2: Perform the pairwise comparisons.

In this step, comparison matrices are formed and pairwise comparisons are conducted. Decision criteria are compared in the corresponding level using fundemental comparison scale. The table below shows the comparison scale used by AHP.

Table 2. The fundamental scale for pairwise comparison

\begin{tabular}{cc}
\hline Intensity of importance & Explanation \\
\hline $\mathbf{1}$ & Two activities or criteria contribute equally to the \\
objective
\end{tabular}

This pairwise comparison can be shown by a square and reciprocal matrix, (see Eq. (1)). The result of the pairwise comparison on $n$ criteria can be summarized in an $(n \times n)$ evaluation matrix.

$$
A=\left(\mathrm{a}_{i j}\right)_{n \times n}=\left[\begin{array}{cccc}
\mathrm{a}_{11} & \mathrm{a}_{12} & \ldots & \mathrm{a}_{1 n} \\
\mathrm{a}_{21} & \mathrm{a}_{22} & \ldots & \mathrm{a}_{2 n} \\
\cdot & \cdot & \cdot & \cdot \\
\cdot & \cdot & \cdot & \cdot \\
\cdot & \cdot & \cdot & \cdot \\
\mathrm{a}_{n 1} & \mathrm{a}_{n 2} & \cdot & \mathrm{a}_{n n}
\end{array}\right]
$$

Step 3: Calculating the relative importance weights.

In the last step, each matrix is normalized and perform calculations to check consistency. Via normalization, the normalized weight vectors and priority of criteria can be obtained.

The number 0.1 is the accepted upper limit for consistency ratio (CR) (Dağdeviren et al., 2009). The CR is calculated as the ratio of the consistency index (CI) and the random index (RI). The CI and CR can be computed with the use of following equations: 


$$
\begin{aligned}
& C I=\frac{\lambda_{\text {max }}-n}{n-1} \\
& C R=\frac{C I}{R I}
\end{aligned}
$$

Table 3. Random index (Saaty, 1980)

\begin{tabular}{ccccccccc}
\hline $\boldsymbol{n}$ & $\mathbf{1}$ & $\mathbf{2}$ & $\mathbf{3}$ & $\mathbf{4}$ & $\mathbf{5}$ & $\mathbf{6}$ & $\mathbf{7}$ & $\mathbf{8}$ \\
\hline $\mathbf{R I}$ & 0.00 & 0.00 & 0.58 & 0.90 & 1.12 & 1.24 & 1.32 & 1.41 \\
\hline
\end{tabular}

\subsection{MOORA Method}

The MOORA method, first used by Brauers (2003), is relatively new multi-criteria decision making method. The method based on ratio system and dimemsionless measurement (Brauers et al., 2008, 2010).

MOORA method is composed of five major steps (Brauers and Zavadskas, 2006; Chakraborty, 2011; Gadakh, 2011; El-Santawy and Ahmed, 2012):

Step 1: Creating the decision matrix.

The method starts with a decision matrix of responses of different alternatives to evaluation criteria.

$$
X=\left[\begin{array}{cccc}
x_{11} & x_{12} & \ldots & x_{1 n} \\
x_{21} & x_{22} & \ldots & x_{2 n} \\
\cdot & & & \cdot \\
\cdot & & & \cdot \\
\cdot & & & \cdot \\
x_{m 1} & x_{m 2} & \ldots & x_{m n}
\end{array}\right]
$$

where $x_{i j}$ is the performance measure of ith alternative on $j$ th criteria, $m$ is the number of alternatives, and $n$ is the number of criteria.

Step 2: Normalization procedure.

MOORA refers to a ratio system in which each response of an alternative on criteria is compared to a denominator, which is representative for all alternatives concerning that objective. This ratio can be expressed as below:

$$
x_{i j}^{*}=\frac{x_{i j}}{\sqrt{\sum_{i=1}^{m} x_{i j}^{2}}} \quad(j=1,2, \ldots, n)
$$

where $x_{i j}{ }^{*}$ is a dimensionless number which belongs to the interval $[0,1]$ representing the normalized performance of $i$ th alternative on $j$ th criteria.

Step 3: Evaluation of positive and negative effects. 
For optimization, these normalized performances are added in case of maximization (for beneficial criteria) and subtracted in case of minimization (for nonbeneficial or cost criteria) by solving the following equation:

$y_{i}=\sum_{j=1}^{g} x_{i j}^{*}-\sum_{j=g+1}^{n} x_{i j}^{*}$

where $\mathrm{g}$ is the number of criteria to be maximized, $(\mathrm{n}-\mathrm{g})$ is the number of criteria to be minimized, and $y_{i}$ is the normalized assessment value of $i$ th alternative with respect to all the criteria.

Step 4: Determine the weighted assessment value.

Generally, it is often observed that some decision criteria are more important than the others. In order to increase priority of criteria, it could be multiplied with its weight. When these criteria weights are taken into consideration, Eq. 7 becomes as follows:

$y_{i}^{*}=\sum_{j=1}^{g} w_{j} x_{i j}^{*}-\sum_{j=g+1}^{n} w_{j} x_{i j}^{*} \quad(j=1,2, \ldots, n)$

where $w_{j}$ is the priority of $j$ th criteria, which can be assigned using different multi-criteria decision making method.

Step 5: Ranking of alternatives.

Decision alternatives should be ranked the preference order according to decreasing values of $y_{i}{ }^{*}$. Assessment value can be positive or negative depending of criteria situation and priority values.

\section{The Application for Bank Branch Location Selection}

In order to solve the bank branch location selection problems and rank the location alternatives, integrated AHPMOORA model is proposed. The general structure of our methodology is given in the Figure 3. 


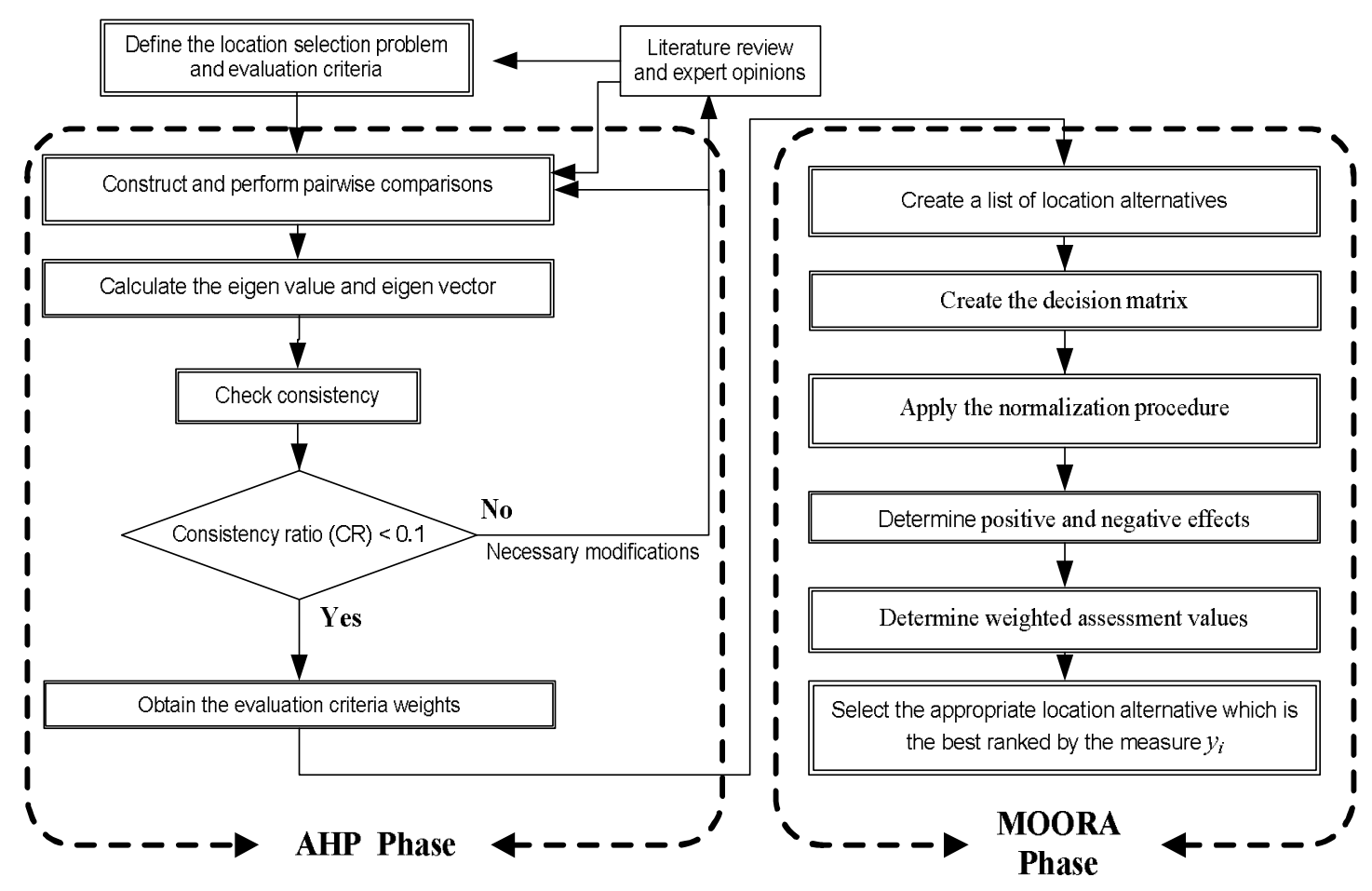

Figure 3. General structure of the location selection framework

\subsection{Determining priorities of evaluation criteria}

In the first step of the solution, AHP is applied to assign priorities of criteria. To construct the pairwise comparison matrices for the evaluation criteria, an expert team constituted. Three decision makers from XYZ Bank, namely general manager, head of branch network development department, head of strategic planning department, and two academician from department of banking and capital markets constructed an expert team for determine consensus criteria priorities. Comparison matrices of main and sub-criteria and global priority weights of evaluation criteria and their ranking have been presented in Table 4-8.

Table 4. The pairwise comparison matrix of the main criteria

\begin{tabular}{|c|c|c|c|c|}
\hline Criteria & $\mathbf{C}_{1}$ & $\mathbf{C}_{2}$ & $\mathbf{C}_{3}$ & Weights \\
\hline $\mathrm{C}_{1}$ Demographic criteria & 1 & $1 / 3$ & $1 / 5$ & 0.115 \\
\hline $\mathrm{C}_{2}$ Economic criteria & 3 & 1 & 1 & 0.405 \\
\hline $\mathrm{C}_{3}$ Investment and Banking criteria & 5 & 1 & 1 & 0.480 \\
\hline
\end{tabular}

Table 5. The pairwise comparison matrix of the demographic criteria

\begin{tabular}{|c|c|c|c|c|}
\hline Criteria & $\mathrm{C}_{1}$ & $\mathrm{C}_{2}$ & $\mathrm{C}_{3}$ & Weights \\
\hline $\mathrm{C}_{11}$ Total population & 1 & 2 & 1 & 0.411 \\
\hline$C_{12}$ Literacy rate & $1 / 2$ & 1 & 1 & 0.261 \\
\hline $\mathrm{C}_{13}$ Urbanization rate & 1 & 1 & 1 & 0.328 \\
\hline
\end{tabular}


Table 6. The pairwise comparison matrix of the economic criteria

\begin{tabular}{lccccc}
\hline \multicolumn{1}{c}{ Criteria } & $\mathbf{C}_{\mathbf{1 1}}$ & $\mathbf{C}_{\mathbf{1 2}}$ & $\mathbf{C}_{\mathbf{1 3}}$ & $\mathbf{C}_{\mathbf{1 4}}$ & Weights \\
\hline $\mathrm{C}_{21}$ Gross domestic product & 1 & $1 / 2$ & 3 & $1 / 3$ & 0.461 \\
$\mathrm{C}_{22}$ Spending on education & 2 & 1 & 6 & 1 & 0.073 \\
$\mathrm{C}_{23}$ Employment rate & $1 / 3$ & $1 / 6$ & 1 & $1 / 3$ & 0.310 \\
$\mathrm{C}_{24}$ Inflation rate in consumer prices & 3 & 1 & 3 & 1 & 0.156 \\
\hline $\mathrm{CR}=0.044$ & & & & & \\
\hline
\end{tabular}

Table 7. The pairwise comparison matrix of investment and banking criteria

\begin{tabular}{lccccc}
\hline \multicolumn{1}{c}{ Criteria } & $\mathbf{C}_{\mathbf{1 1}}$ & $\mathbf{C}_{\mathbf{1 2}}$ & $\mathbf{C}_{\mathbf{1 3}}$ & $\mathbf{C}_{\mathbf{1 4}}$ & Weights \\
\hline $\mathrm{C}_{21}$ Total business spending on investment & 1 & 3 & 5 & 2 & 0.456 \\
$\mathrm{C}_{22}$ Number of domestic companies listed on the stock exchange & $1 / 3$ & 1 & 3 & $1 / 3$ & 0.152 \\
$\mathrm{C}_{23}$ Bank capital to assests ratio & $1 / 5$ & $1 / 3$ & 1 & $1 / 5$ & 0.068 \\
$\mathrm{C}_{24}$ Domestic credit by banking sector & $1 / 2$ & 3 & 5 & 1 & 0.324 \\
\hline $\mathrm{CR}=0.039$ & & & & & \\
\hline
\end{tabular}

Table 8. Overall priority weights of evaluation criteria

\begin{tabular}{|c|c|c|c|c|}
\hline Main Criteria & Priority & Sub-Criteria & $\begin{array}{c}\text { Priority within } \\
\text { the Cluster }\end{array}$ & $\begin{array}{l}\text { Overall } \\
\text { Priority } \\
\end{array}$ \\
\hline \multirow{3}{*}{$\begin{array}{l}\text { Demographic } \\
\text { criteria }\end{array}$} & \multirow{3}{*}{0.115} & Total population & 0.411 & 0.047 \\
\hline & & Literacy rate & 0.261 & 0.030 \\
\hline & & Urbanization rate & 0.328 & 0.038 \\
\hline \multirow{4}{*}{ Economic criteria } & \multirow{4}{*}{0.405} & Gross domestic product & 0.461 & 0.187 \\
\hline & & Spending on education & 0.073 & 0.029 \\
\hline & & Employment rate & 0.310 & 0.126 \\
\hline & & Inflation rate in consumer prices & 0.156 & 0.063 \\
\hline \multirow{4}{*}{$\begin{array}{l}\text { Investment and } \\
\text { Banking criteria }\end{array}$} & \multirow{4}{*}{0.480} & Total business spending on investment & 0.456 & 0.219 \\
\hline & & $\begin{array}{l}\text { Number of domestic companies listed on the } \\
\text { stock exchange }\end{array}$ & 0.152 & 0.073 \\
\hline & & Bank capital to assests ratio & 0.068 & 0.033 \\
\hline & & Domestic credit by banking sector & 0.324 & 0.155 \\
\hline
\end{tabular}

According to AHP result XYZ Bank give more importance to "total business spending on investment", "gross domestic product", "domestic credit by banking sector" and "employment rate" in determining the best location alternative.

\subsection{Ranking of the location alternatives}

After the pairwise comparisons and determine of the weights of criteria with respect to the goal, alternatives are evaluated with criteria values of location alternatives by MOORA method. Four possible country location alternatives $\left(\mathrm{L}_{1}, \mathrm{~L}_{2}, \mathrm{~L}_{3}\right.$ and $\left.\mathrm{L}_{4}\right)$ are evaluated to open new bank branch. Decision matrix includes values for evaluation criteria to alternative locations are given in Table 9. 
Table 9. Values for evaluation criteria to alternative locations

\begin{tabular}{l|c|c|c|c}
\hline \multirow{2}{*}{ Evaluation Criteria } & \multicolumn{3}{c}{ Alternative Locations } \\
\cline { 2 - 5 } & \multicolumn{2}{c}{$\mathbf{L}_{\mathbf{1}}$} & $\mathbf{L}_{\mathbf{2}}$ & $\mathbf{L}_{3}$ \\
\hline Total population & 7400000 & 33500000 & 10850000 & 29200 \\
\hline Literacy rate (\%) & 98.4 & 78.2 & 96.0 & 86.6 \\
\hline Urbanization rate (\%) & 73.1 & 66.5 & 61.4 & 82.3 \\
\hline Gross domestic product (millions of US \$) & 50800 & 144600 & 255000 & 657000 \\
\hline Spending on education (\% of GDP) & 4.1 & 4.1 & 4.0 & 5.6 \\
\hline Employment rate & 90.1 & 84.0 & 75.6 & 89.3 \\
\hline Inflation rate in consumer prices & 2.4 & 6.4 & 1.1 & 4.6 \\
\hline Total business spending on investment (\% of GDP) & 20.4 & 10.1 & 10.4 & 21.5 \\
\hline Number of domestic companies listed on the stock exchange & 393 & 347 & 275 & 150 \\
\hline Bank capital to assests ratio (\%) & 10.6 & 8.0 & 6.3 & 12.9 \\
\hline
\end{tabular}

Table 10. Dimensionless number $\left(x_{i j}{ }^{*}\right)$ for each location alternative

\begin{tabular}{lcccccccccccc}
\hline & $\mathbf{C}_{\mathbf{1 1}}$ & $\mathbf{C}_{\mathbf{1 2}}$ & $\mathbf{C}_{\mathbf{1 3}}$ & $\mathbf{C}_{\mathbf{2 1}}$ & $\mathbf{C}_{\mathbf{2 2}}$ & $\mathbf{C}_{\mathbf{2 3}}$ & $\mathbf{C}_{\mathbf{2 4}}$ & $\mathbf{C}_{\mathbf{3 1}}$ & $\mathbf{C}_{\mathbf{3 2}}$ & $\mathbf{C}_{\mathbf{3 3}}$ & $\mathbf{C}_{\mathbf{3 4}}$ \\
\hline Location 1 & 0.206 & 0.546 & 0.513 & 0.070 & 0.456 & 0.530 & 0.289 & 0.618 & 0.643 & 0.542 & 0.373 \\
\hline Location 2 & 0.931 & 0.434 & 0.467 & 0.200 & 0.456 & 0.494 & 0.770 & 0.306 & 0.568 & 0.409 & 0.195 \\
\hline Location 3 & 0.302 & 0.532 & 0.431 & 0.354 & 0.444 & 0.445 & 0.132 & 0.315 & 0.450 & 0.322 & 0.801 \\
\hline Location 4 & 0.001 & 0.480 & 0.578 & 0.911 & 0.622 & 0.526 & 0.553 & 0.652 & 0.246 & 0.660 & 0.426 \\
\hline Criteria Weight & 0.047 & 0.030 & 0.038 & 0.187 & 0.029 & 0.126 & 0.063 & 0.219 & 0.073 & 0.033 & 0.155 \\
\hline Criteria Situation & $(+)$ & $(+)$ & $(+)$ & $(+)$ & $(+)$ & $(+)$ & $(-)$ & $(+)$ & $(+)$ & $(+)$ & $(+)$ \\
\hline
\end{tabular}

Table 11. Weighted assessment values $\left(y_{i}{ }^{*}\right)$ and ranking for location selection problem

\begin{tabular}{ccccc}
\hline Alternative & Benefit Criteria & Cost Criteria & $\boldsymbol{y}_{\boldsymbol{i}}{ }^{*}$ & Rank \\
\hline Location 1 & 0.397 & 0.018 & 0.379 & 3 \\
Location 2 & 0.340 & 0.049 & 0.291 & 2 \\
Location 3 & 0.418 & 0.008 & 0.410 & $\mathbf{1}$ \\
Location 4 & 0.539 & 0.035 & 0.504 & $\mathbf{1}$ \\
\hline
\end{tabular}


Based on evaluation criteria weights obtained by AHP, the results of MOORA, as present in Table 10, occur the ranking of alternatives as $\mathrm{L}_{4}, \mathrm{~L}_{3}, \mathrm{~L}_{1}$ and $\mathrm{L}_{2}$. Decision matrix for MOORA method with criteria weight and dimensionless number calculations are presented in Table 9. In Table 10, the benefit, cost, and weighted assessment values are listed for all location alternatives MOORA ranking results show that Location-4 is the best choice among the four location alternatives.

\section{Conclusions}

Bank branch location is a critical issue to evaluate the banking performance. Although, there are a lot of studies on the bank branch performance, comprehensive parameters on the international branch location are so limited for the best location selection. The study covers the banking-based determinants as well as investment, economic and demographic factors. In this study, AHP method has been used to construct the weights of decision criteria and MOORA has been also applied to determine the best alternative for the new bank branch location. The empirical study shows that the most important criteria is determined as "total business spending on investment" and Location-4 is chosen among the four branch location alternatives. According to the weights of criteria, overall priority of demographic factors is relatively less than other main criteria. However, Experts' choices indicate that investment and banking criteria have a strategic role in the best location selection decision. Especially, spending on investment, domestic product and credit demand have the first three ranks in the weights of criteria. The result demonstrates that domestic credit demand may enhance due to the increasing investment and production in the target location, thus the bank branch can get more profitable and productive than other locations.

\section{References}

Albayrak, E. \& Erensal, Y. C, (2004). Using analytic hierarchy process (AHP) to improve human performance. An application of multiple criteria decision making problem, Journal of Intelligent Manufacturing, 15, 491-503.

Athanassopoulos, Antreas D. (1997). Service quality and operating efficiency synergies for management control in the provision of financial services: Evidence from Greek bank branches. European Journal of Operational Research, 98, 300-313.

Berger, Allen N. Leusner, John H. Mingo, John J. (1997). The efficiency of bank branches. Journal of Monetary Economics, 40, 141-162.

Boufounou, Paraskevi V. (1995). Evaluating bank branch location and performance: A case study. European Journal of Operational Research, 87, 389-402.

Brauers, W. K. M. (2003). Optimization methods for a stakeholder society: A revolution in economic thinking by multi-objective optimization, Nonconvex Optimization and Its Applications, Kluwer Academic Publishers.

Brauers, W. K. M. \& Zavadskas, E. K. (2006). The MOORA method and its application to privatization in a transition economy. Control and Cybernetics. 35 (2), 445-469.

Brauers, W. K. M. \& Zavadskas, E. K. (2009). Robustness of the multi-objective MOORA method with a test for the facilities sector, Technological and Economic Development of Economy, 15(2), 352-375.

Brauers, W. K. M., Ginevičius, R. \& Podvezko, V. (2010). Regional development in Lithuania considering multiple objectives by the MOORA method, Technological and Economic Development of Economy, 16(4), 613-640.

Brauers, W. K. M., Zavadskas, E. K. Turskis, Z. \& Vilutiene, T. (2008). Multi-Objective contractors's ranking by applying the MOORA method. Journal of Business Economics and Management, 9 (4), 245-255.

Cerutti, Eugenio. Dell'Ariccia, Giovanni. Peria, Maria Soledad Martinez. (2007). How banks go abroad: Branches or subsidiaries? Journal of Banking \& Finance, 31, 1669-1692.

Chakraborty, S. (2011). Applications of the MOORA method for decision making in manufacturing environment. The International Journal of Advanced Manufacturing Technology, 54 (9-12), 1155-1166.

Dağdeviren, M., Yavuz, S. \& Kılınç, N. (2009). Weapon selection using the AHP and TOPSIS methods under fuzzy environment. Expert Systems with Applications, 36, 8143-8151.

Dekker, David. Post, Thierry. (2001). A quasi-concave DEA model with an application for bank branch performance evaluation. European Journal of Operational Research, 132, 296-311.

El-Santawy, M. F. \& Ahmed, A. N. (2012). Analysis of project selection by using SDV-MOORA approach, Life Science Journal, 9, 167-170.

Gadakh. V. S. (2011). Application of MOORA method for parametric optimization of milling process, International Journal of Applied Engineering Research, 1 (4), 743-758.

Giokas, Dimitris I. (2008). Assessing the efficiency in operations of a large Greek bank branch network adopting 
different economic behaviors. Economic Modelling, 25, 559-574.

Hirtle, Beverly. (2007). The impact of network size on bank branch performance. Journal of Banking \& Finance, 31, 3782-3805.

Karande, P. \& Chakraborty, S. (2012). Application of multi-objective optimization on the basis of ratio analysis (MOORA) method for materials selection. Materials and Design, 37, 317-324.

Liang, Hsin-Yu. Ching, Yann Peng. Chan, Kam C. (2013). Enhancing bank performance through branches or representative offices? Evidence from European banks. International Business Review, 22, 495-508.

Liu, C., Serrano, A. R., Yin, G. (2012). An optimum design selection approach for product customization development, Journal of Intelligent Manufacturing, 23 (4), 1433-1443.

Manandhar, Raman. Tang, John C. S. (2002). The evaluation of bank branch performance using data envelopment analysis A framework. Journal of High Technology Management Research, 13, 1-17.

Meepadung, Napapan. Tang, John C.S. Khang Do Ba. (2009). IT-based banking services: Evaluating operating and profit efficiency at bank branches. Journal of High Technology Management Research, 20, 145-152.

Paradi, Joseph C. Rouatt, Stephen. Zhu, Haiyan. (2011). Two-stage evaluation of bank branch efficiency using data envelopment analysis. Omega, 39, 99-109.

Paradi, Joseph C. Zhu, Haiyan. Edelstein, Barak. (2012). Identifying managerial groups in a large Canadian bank branch network with a DEA approach. European Journal of Operational Research, 219, 178-187.

Ramirez, Carlos D. (2003). Did branch banking restrictions increase bank failures? Evidence from Virginia and West Virginia in the late 1920s. Journal of Economics and Business, 55, 331-352.

Saaty, T. L. (1980). The analytic hierarchy process: Planning priority setting. McGraw Hill, New York.

Saaty, T. L. (1990). How to make a decision: The analytic hierarchy process. European Journal of Operational Research, 48: 9-26.

Saaty, T. L. (2008). Decision making with the analytic hierarchy process. International Journal of Service Sciences, 1 (1): 83-98.

Shyu, Jonchi. Chiang, Terri. (2012). Measuring the true managerial efficiency of bank branches in Taiwan: A threestage DEA analysis. Expert Systems with Applications, 39, 11494-11502.

Spyropoulos, Giorgos N. Balaras, Constantinos A. (2011). Energy consumption and the potential of energy savings in Hellenic office buildings used as bank branches: A case study. Energy and Buildings, 43, 770-778.

Wu, Desheng. Yang, Zijiang. Liang, Liang. (2006). Efficiency analysis of cross-region bank branches using fuzzy data envelopment analysis. Applied Mathematics and Computation, 181, 271-281. 